\title{
IMPACT OF AGRICULTURAL LAND USE ON SOME HUNGARIAN KARST REGIONS
}

\author{
Ilona Bárány-Kevei
}

\section{ABSTRACT}

The karst regions are found in the medium altitude mountains of Hungary. Their land use types are natural and sustainable forestry, grazing and vineyards. In international comparison, Hungary belongs to those countries of Europe where arable land is abundant, therefore, in the future its extension has to be reduced. That means agricultural activity has to be restricted on the sensitive karst surfaces. This paper presents ways of sustainable forestry and other land use types for three karst regions of Hungary.

KEY WORDS: Hungary, human impact on karst, nature conservation.

\section{Introduction}

The majority of the Hungarian karst terrains is situated in the Transdanubian and Northern Mountain Ranges: only smaller patches of isolated karsts are found in the north-western and southern parts of Transdanubia (Fig. 1). Somewhat less than $1.5 \%$ of the area of Hungary is limestone and dolomite karst (Jakucs, 1977). Parts of the

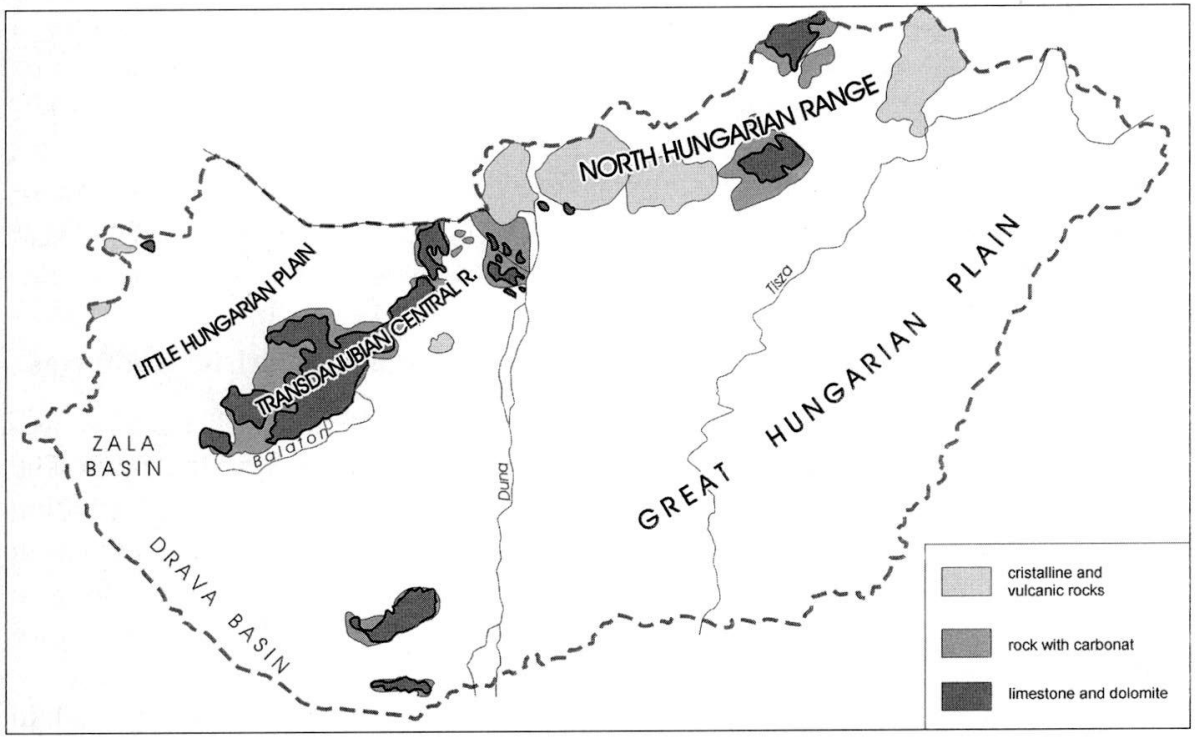

Fig. 1 Hungarian Mountains Range 
Bakony, Vértes, Budai and the Mecsek Mountains are nature conservation areas. The karst regions of Aggtelek and Bükk Mountains are National Parks. All of the caves of Hungary (3179) are protected. The karstic mountains of Hungary are built up of Triassic limestones and dolomites, which are well karstified.

The tectonic movements were intensive in the Transdanubian Mountains; thus, a lot of horsts and grabens were formed. This formation is called the "Transdanubian type" of karst. Nevertheless, in Northern Hungary, less faulted and characteristic karst forms also developed, and this type is distinguished as the "Aggtelek type". Moreover, the Mecsek Mountains and Villányi Range are classified as Aggtelek type karsts.

During the different geological periods, intensive karstification processes occurred on several occasions. Thus, traces of the Cretaceous and Tertiary karst formation can be found in the Bakony and Aggtelek Mountains. This means that the forms of both fossil and recent karst formations occur on Hungarian karsts. As an effect of the Tertiary and Quaternary tectonic activities, a part of the karst surfaces have deeply subsided and today are only revealed in deep boreholes.

During the last decades, nature conservation in land use has received a rather strong emphasis in Hungary. With the establishment of the Bükk and the Aggtelek National Parks, two of our really important karst regions acquired protection, but also the rest of the karst areas are under nature conservation regulations. The majority of Hungarian karst regions are situated in mountainous areas, and unsuitable for intensive farming and are also under threat from soil erosion. The karst terrains constitute significant areas of forestry and grazing. Therefore, in any case, it is important to examine how sustainable agricultural land use of karst can be planned. The karst terrains of Hungary are important resources for drinking water, and require more effective protection in the future. Moreover, in the course of their agricultural land use, nature conservation regulations - concerning a particular area - have to be observed. In Hungary, the Nature Conservation Act of 1996 claims that in karst terrains every spring with at least $5 \mathrm{l} / \mathrm{min}$ water yield is protected. It is also true for sinkholes and caves or caverns. Endemic flora and fauna species as well as their biotopes are also protected. This means that anthropogenic alteration of natural ecological conditions can only be minimal in the strictly protected areas.

\section{The structure of Hungarian karst terrains and their characteristic landforms.}

The karst terrains of Hungary are also rich in subsurface features. The intense tectonic movements fragmented the tectonic units of the Transdanubian Mountains. The karst of the Mecsek Mountains folded: this process hindered the extensive formation of the subsurface caverns. Moreover, hydrothermal karst phenomena are common in the Buda Mountains, which are also linked to tectonic movements. The uplifting in the Bükk and Aggtelek Mountains was accompanied by no significant folding or faulting, and large undisturbed systems of caverns formed.

The most extensive karst regions can be found in the Transdanubian Mountain Range (Fig.1). From the south-west, the first one is the dolomite karst of the 
Keszthely Hills which is adjoined by the karst of the Balaton Highlands (with older Devonian and Sarmatian limestone). The karst areas of the Southern Bakony Ranges are built up mainly of Dachstein dolomite. (Triassic Rhaetic layer), but also the Muschelkalk (Triassic Anysian, Ladinian) limestone constituents of the karst.

Mesozoic karst terrains are the Vértes and the Gerecse. The Pilis Mountains and Budai Hills (Wetterstein and Budaörs dolomites) are composed of dolomite and limestone. The hydrothermal phenomena and forms are characteristic karst features here. The Triassic and Jurassic limestone karst of the Mecsek mountains, the karst of the Villány Range (with the Cretaceous limestone of Nagyharsány) together with the Beremend Horst as well as the Leitha limestone horst adjacent to the Fertö lake (Neusiedler See) all stand out as isolated hills in Transdanubia.

The typical karst phenomena of the Bükk Mountains are formed of Triassic limestone. The most significant products of the Triassic period here is the limestone of the Greater Plateau and of the Smaller Plateau of Répáshuta as well as the Hámor dolomite. The extended karst highland limestone was covered by Ladinian, Carnian and Noric sediments. The upper Triassic limestone of the Smaller Plateau is a light Megalodontic limestone.

The Aggtelek Mountains with the Rudabánya Mountains are the southern extension of the Gömör-Tornai Karst. It is not only exposed on the surface but it also has subsurface connections to the Baradla and Domica caves. The cave system called Baradla is the longest, its total length is 24,816 m together with the Domica cavern; from this, $18,836 \mathrm{~m}$ are in Hungary. The main enclosing rocks are the Gutenstein thin-layered greyish-black and the light grey Wetterstein-Ladinian limestones and dolomites.

As mentioned above, tectonic activities played an important role in the karst terrains of Hungary. In the karst regions of the Transdanubian Mountains, transversal faults were created perpendicular to the northeastern-southwestern main tectonic axis. Hydrothermal karst phenomena are a result of tectonism in the Transdanubian Mountains. Hydrothermal phenomena are common in the Main Dolomite (Jakucs, 1977).

\section{The impacts of agricultural land use on the karst terrains.}

As the karst terrains in Hungary are situated in mountains, forestry and grazing are the most important agricultural activities in these areas. A significant part of them enjoys a certain level of protection. In this paper the cases of Bükk, Aggtelek Mountains and Villány Hills will be discussed. The first two of these areas are already national parks today, and a part of the Villány Hills (Templomhegy) is a Nature Reserve.

\subsection{Sustainable forestry on the Bükk Highlands}

In 1977, the Bükk National Park was established as the third national park, it extends over a surface of 9,661.865 hectares in the Bükk Mountains, 95\% of which is covered by forest. Additionally, it has 853 caves and the deepest cavern of the 
country: the István-lápa cavern that is $250 \mathrm{~m}$ deep and $454 \mathrm{~m}$ long. It is famous for its dry spring caves, which served as a dwelling place for the ancient human population of the area (Istállóskö, Szeleta and Subalyuk caves).

From 1514 to 1945 it was a state forest area. From 1818 onwards plantations were established. Grazing and deforestation were significant until 1880. In 1935, a new type of forest law was introduced which changed the natural characteristics of the landscape. After 1945 deforestation was too intensive, especially on the western parts where clear-cutting occurred, as a profitable forestry was identified as a primary objective. From 1977, following the establishment of the National Park more natural sustainable forestry became dominant (In 1972, at the FAO convention in Buenos Aires, the Hungarian approach was accepted: forests have a triple function: economic, conservation and recreation).

The ownership changed in 1989. The ownership changes led to the partition of the state forest area. Since 1996, several laws have decreased the protection of the forests from grazing as well as the protection of the environment.

In the National Park, as a consequence of reforestation, the fundamental land use is forestry (Fig. 2), while, however, small patches of arable land are found in the vicinity of settlements. Forests, together with meadows and grazing lands are semi-natural land use types.

The timber mass in the Bükk National Park is 8 million $\mathrm{m}^{3}$. As only $18 \%$ of Hungary is covered by forests, this area cannot be excluded from timber production. At the same time, excessive exploitation increases the soil erosion hazard especially on the Highlands, where rendzina and brown forest soils can be found. Reforestation

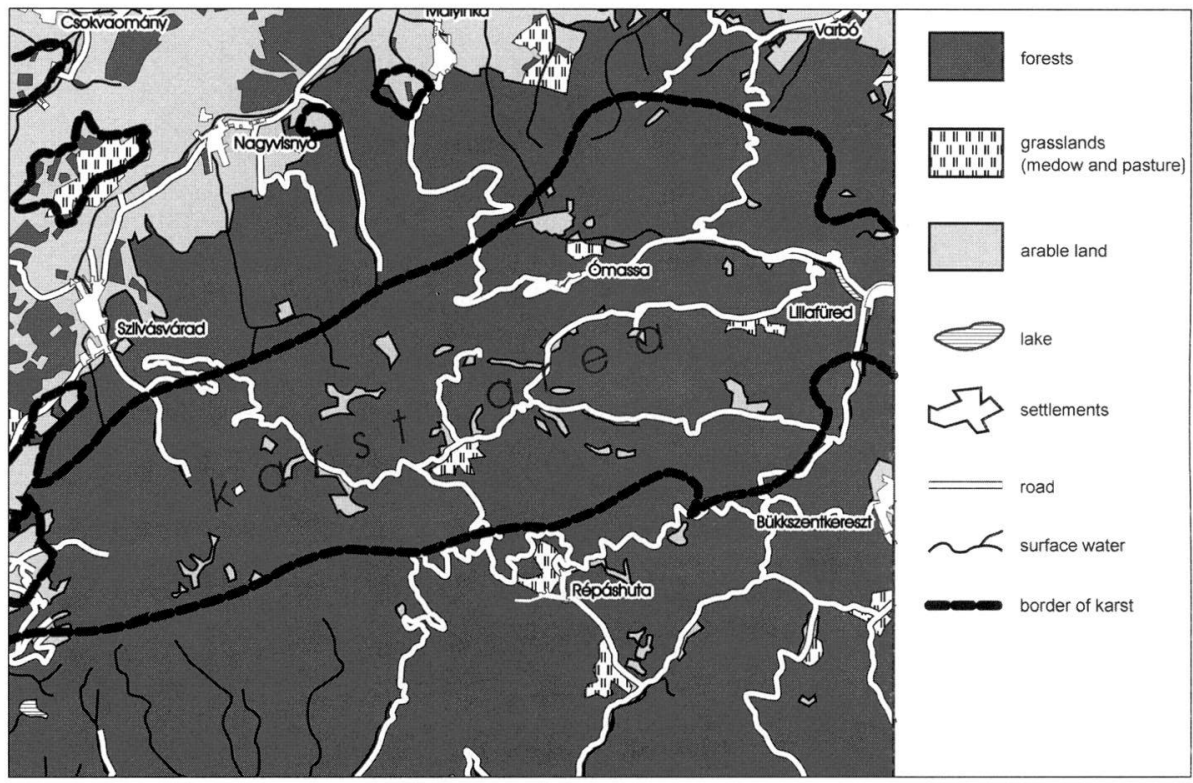

Fig. 2 - Land use in the Bükk Mountains. 
remained unsuccessful on the site of cleared woodlands. Forests have a great importance in the uniform infiltration of precipitation water, thus, it is very important from the point of view of karst protection.

With increasing elevation above sea level, several zones of forests can be distinguished:

a) up to the elevation of 200-250 m forests with maple and hornbeam (Aceri-campestri-Quercetum petreae-roboris, Quercus pubescens and Q.petreae) are found.

b) to the height of $450 \mathrm{~m}$ turkey oaks occur (Quercus petreae-cerris).

c) in the elevation between 400 and $600 \mathrm{~m}$ the, hornbeam-oak forests (Querco robori-Carpinetum) can occur on any basement rock.

d) at the elevation of 600-700 m, sub-montane beech forests (Melittio fagetum) occur with hornbeam and oak. Even small changes will cause fast deterioration of the environmental here.

e) on the typical karst terrains of the Highlands, dry forests (Aconito fagetum) occur over $800 \mathrm{~m}$ of elevation.

The deforestation of the late 19th century caused severe damage. Special grass and meadow types (Festuco ovinae-Nardetum) formed in their sites to replace them. At the bottom of dolines, daily recurrence of frost hinders the recovery of beech trees.

Their azonal forest associations reflect topographic, rock, soil and microclimatic conditions. In these associations, a lot of endemic and relict species found only here in Hungary have survived. Rock beech forests (Seslerio hungaricae-Fagetum) thrive on northern slopes, whereas karst scrub forests (Cotino-Quercetum pubescentis) live on surfaces with rather shallow, easily warming soils. Fig. 3 shows the species of trees on the High Plateau.

\begin{tabular}{|c|c|c|}
\hline Age group & Year & Percentage (\%) \\
\hline 1 & $1-10$ & 2 \\
\hline 2 & $11-20$ & 7 \\
\hline 3 & $21-30$ & 10 \\
\hline 4 & $31-40$ & 8 \\
\hline 5 & $41-60$ & 22 \\
\hline 6 & $61-80$ & 20 \\
\hline 7 & $81-100$ & 17 \\
\hline 8 & $>100$ & 14 \\
\hline
\end{tabular}

Today the steppe-meadow and steppeswards, typical of karst terrains, occur only at a rate of $0.8 \%$ of all the area of the karst terrain. The predominant associations of dolines are the subalpine limestone rock-sward (Campanulo - Festucetum pallentis) under microclimatic inversion.

In the 1994, the age composition of the forest in the Bükk National Park was the following: $50 \%$ of the commercial forests is between 20 and 60 years old, above $70 \%$ of the protected forests are more than 60 years old. After clearings ash tree renewals have developed on the site of beech trees, whereas hornbeam renewals have replaced oaks in clearings.

There are two old forest areas in the region. One of them is the primeval pine forest in Jávorkút, planted in 1815; the other one is the backwoods called "Öserdö" where in 1946 any kind of forest management was prohibited. From the 1960s to the 1980s, the excessive timber felling decreased the share of the old forest areas.

The aim of sustainable forestry is to manage forests in such a way that its con- 


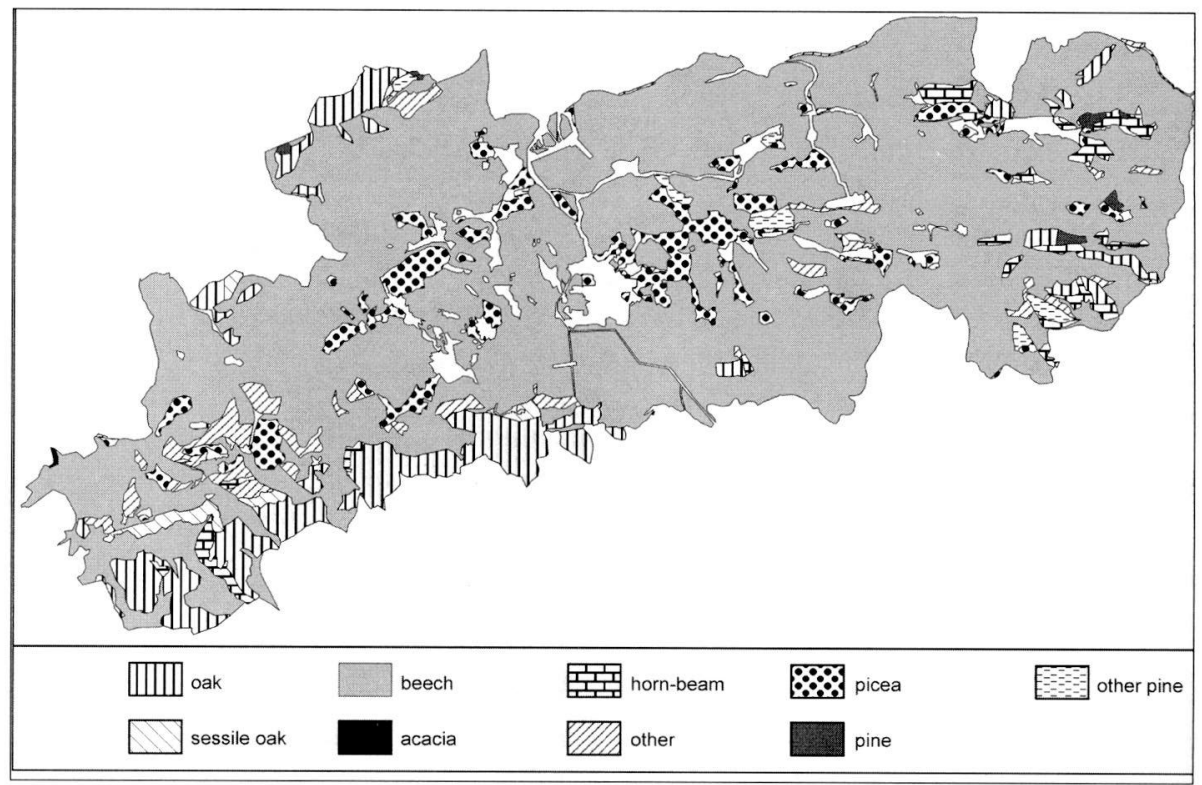

Fig. 3 - Tree species of the High Plateau of the Bükk Mountains.

servation and recreational functions can continue their existence overlong periods of time. At the same time, it should preserve its biological diversity, its semi-natural conditions, its capability to recover and its vitality. It should also unite conservation and economic requirements in accordance with social demands. Moreover, it should satisfy health, social, tourist as well as educational and research demands (Keszthelyi et al., 1995).

In the Bükk National Park $70 \%$ of the forests are commercial forest, $29 \%$ is protected and $1 \%$ is amenity forests. It is shown from the above figures that felling should be practised in a way that should not endanger the ecological equilibrium of the forest. From the foundation of the National Park, nature-friendly forestry is practised, which means that clear cutting is only permitted if it ensures the maintenance of the diversity and equilibrium of the ecosystem.

This requires a careful choice of species for the habitat and the application of methods sparing the habitat and the plant. Pine plantation is not allowed, only the renewal of the damaged forests can be made by planting spruces, Douglas firs and Scotch pines. After their future clearing, the spreading of indigenous species can be expected. Pesticides can be applied only where the old forest areas cannot be renewed in any other way, and the area of the connected surface cannot surpass 12.3 hectares. The age for cutting maturity must be raised to 100-120 years in the beech forests and to 120-140 years in the oak forests.

Forestry is feasible in a planned way, plans containing the proportion and age of the tree species. Sustainable forestry has to be implemented without damage to the 
ecosystem. This means that timber should be produced so that it should not decrease the tree layer of the forest, thus, the microclimate does not alter and no damage is done. On the western part of the Bükk Mountains there are trees of nearly the same age. It means that they reach felling maturity at the same date and in order to maintain ecological equilibrium and uninterrupted renewal, the ages of the trees should be prolonged for 130 years. Certainly, it is very important from an esthetical aspect; thus, natural seedling renewals should be ensured. In hornbeam-oak forests, a renewal lasts $15-20$ years whereas this is $25-30$ years in beech forests.

Additionally, one of the important tasks is to maintain recreational functions. Today it is not permitted to enter by car in the area of the Great Plateau; however, further restrictions should be introduced in the use of automobiles along the borders of the National Park.

\subsection{The impacts of land use in the Aggtelek Karst}

Ten years after the establishment of the Aggtelek National Park in 1985, its caves and caverns were declared to be part of the World Natural Heritage in 1995. This means that the protection of the area was further enhanced. The preservation of subsurface geomorphological features requires strict protection at any rate; therefore, the utilisation of surface areas is regulated. As the major part of the Aggtelek Karst is open karst, with shallow soil, the land use of both the immediate karst surface and the adjoining non-karst terrain influence the condition of the karst system. There is significant agricultural activity in the close vicinity and this causes problems in the caves.

$77 \%$ of the National Park is covered with forests (Fig. 4), the main land use type

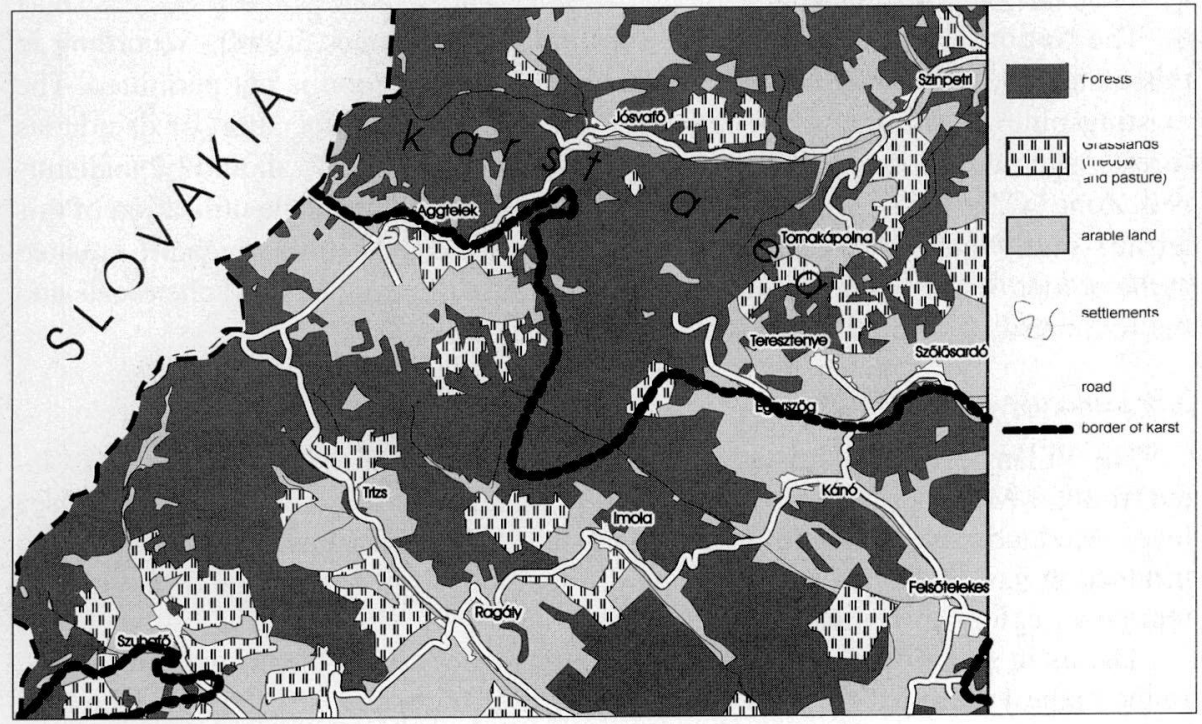

Fig. 4 - Land uses in the Aggtelek Mountains. 
is sustainable forestry. Landscape planning defined forest use for the coming years (1988):

\begin{tabular}{|l|c|}
\hline Forest use & $\%$ \\
\hline Felling & $43.8 \%$ \\
\hline Cultivation for other purposes & $4.6 \%$ \\
\hline Forest for protection & $23 . \%$ \\
\hline Forest for soil protection & $25.8 \%$ \\
\hline Forest for recreational purposes & $1.4 \%$ \\
\hline Forest for other purposes & $0.1 \%$ \\
\hline
\end{tabular}

The mosaic pattern of the landscape was created by natural land use. In this type of land use forestry used to be predominant. Until the establishment of the National Park, forests were felled for timber at high rates. In the clearings grassland developed; and, therefore, hay production dominated.

In the course of forestation, indigenous oak forests and beeches can be planted in the place of pine and acacia forests. Renewal is gradual here and the area of clear cutting cannot surpass 5 hectares, moreover, no contiguous clearings can surpass an area of 3 hectares. In the planted forests the formation of multiple layer associations should emerge. This at the same time serves to protect biodiversity.

The objectives of the Aggtelek National Park also include conservation of karst forms. Therefore, a zonalisation, making the further operation of traditional agriculture possible is introduced. In this way, fodder, fruit and other plant cultivation would be sustainable. This implies certain requirements such as the prohibition of pollutants which endanger natural values (e.g. karst water, stalagmites etc.), and also fertilisers, chemical insecticides which can have an access - through seeping water - to the karst system.

The National Park is planning the creation of three zones (1998). According to this plan, zone " $\mathrm{A}$ " is the natural core area where cultivation is not permitted. The existing pine forests should be replaced, and the natural association of deciduous forests, should be formed. Similarly to the previous, Zone "B" should be undisturbed. Zone " $C$ " is the site for display and traditional agriculture. The utilisation of this terrain- in my opinion - is dangerous, because of the doline rows which are situated at the border of karst and non-karst terrains. The use of pesticides and chemicals and the sediments pollute the water which reaches the caves.

\subsection{Land use in the Villány Hills}

The Villány Hills are situated in the southeastern part of the Transdanubia, isolated from the Mecsek Mountains. Its highest point, the Szársomlyó is $442 \mathrm{~m}$ above sea level. Mediterranean climatic influence prevails, and, accordingly, an area of wine production has developed especially on the southern slopes, (it is one of the important wine regions in Hungary).

The main soil type is rendzina on the southern slopes and the brown forest soils. In the highest region of the hills, the soil layer is shallow and bare karst surfaces can be found in large areas. Hornbeam oak forest (Asperulotaurinae-Carpinetum tilieto- 
sum argenteae) can be found on the steep southern slopes, while the karst scrubs (Inulo spiraeifoliae-Quercetum) as well as the rock and steppe association (SedoFestucetum dalmaticae, Aspleno ruta-murariae, Cleistogeno-festucetum rupicolae) also appear.

The distribution of the associations changes on the different levels of the hills. In the highest area scrub association, below grasslands and almost entirely bare surfaces occur. The pediment surfaces are covered with loess-hornbeam-oak-forests as well as arable land, and vineyards are also to be found there. It is important to note that the natural vegetation is constituted by scrub association on the Upper Jurassic limestone surfaces and by grassland associations on the Lower Cretaceous limestones which indicates the firm connections between the exposed rocks and the flora. The continental and sub-mediterranean flora elements can be found on the Jurassic limestones. Some subatlantic and Balkan flora elements also occur on the terrain (Lehmann, 1975).

In the more distant environment of the Villány Hills extended tillage is practised, which is directly connected to the grape and fruit producing areas (Fig. 5) of the southern slopes. Another human activity; quarrying had already started to a great extent at the turn of century. Recently, mining ceased on the eastern part, where an international open-air sculpture exhibition was established.

In other parts of the area, deforestation of the last century created more arable lands. Under intensive viticulture; this land use caused soil erosion. The settlement

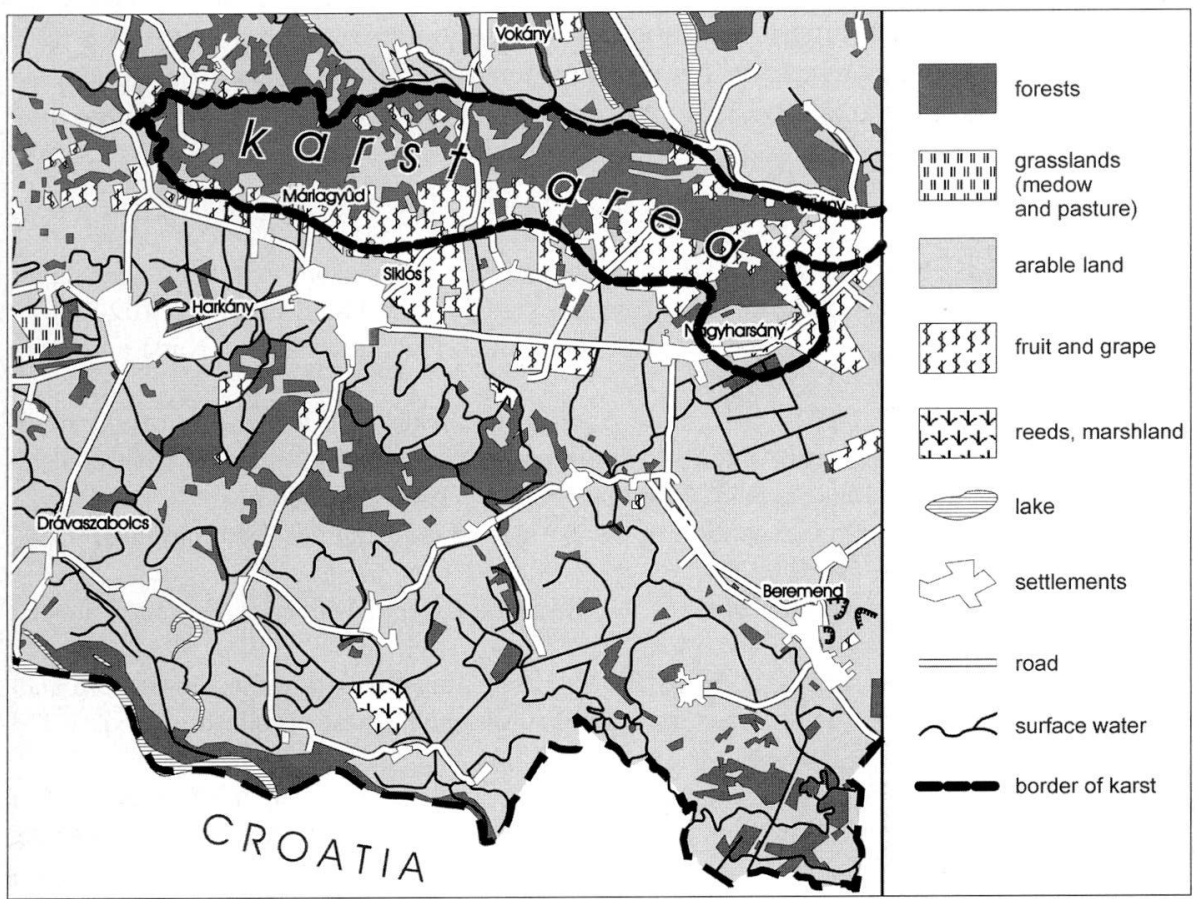

Fig. 5 - Land uses in the Villány Hills and its surroundings. 
pattern is dense in the area and the utilisation of the landscape is mosaic-like. Landforms and rare plants underline the need for the strict protection of the Villány Karsts, which, therefore, should be endeavoured in the near future. This terrain, rich in Mediterranean plant species, should retain its ecological conditions, and reclamation should be practised here only by observing conservation laws.

\section{Conclusion}

The paper tried to present the land use types of three karst terrains in Hungary. Natural, sustainable forestry, grazing and viticulture in favourable areas is practised on the karst.

1. In the Bükk National Park the fundamental land use type is sustainable forestry. Nature conservation and forestry are in conflict with forest management.

2. In the Aggtelek National Park, in addition to sylviculture, grazing is the main agricultural activity. Until the establishing of the National Park, forests were felled for timber at high rates. On the clearings grassland developed; and, therefore, hay production dominated.

3. Extensive farming and viticulture is the land use in the Villány Hills. In the intensive vineyards on karst soil erosion is common.

4. It is an important task for the future to create buffer zones in the interlocking belts of the karst and non-karst areas in order to decrease the harmful environmental impacts of the agricultural activities on the adjoining terrains.

5. In international comparison, Hungary belongs to the countries of Europe where arable lands are extensive. For this reason intensive farming should be banned on the sensitive karst terrains. Tourism and recreation should ensure the economic survival of Hungarian karst areas.

\section{REFERENCES}

BÁRÁNY-KEVEI I., 1985. Ökologische Untersuchung der Karstdolinen unter besonderer Berücksichtigung des Mikroklimas. Acta Geographica Univ. Szegediensis. XXV: 109-30.

BÁRÁNY-KEVEI I., 1998. The geo-ecology of three Hungarian karsts. Karst and Cave Science. Vol. 25 (3): 113-118.

BÁRÁNY-KEVEI I., JAKUCS L., 1984. Szempontok a karsztok felszíni formáinak rendszerezéséhez, különös tekintettel a dolinák típusaira. (Aspects to the systematisation of karst forms, special regard to doline-types). Földrajzi Értesít1. 33 (3): 259-265.

Conservation Utilisation Conception of the Surface of the Aggtelek National Park, 1998. Aggtelek.

JAKUCS L., 1977. Genetic Types of the Hungarian Karst. Karszt és Barlang, Special Issue, 3-7, Budapest.

KESZTHELYI I., CSAPODY I, HALUPA L., 1995. Irányelvek a természetvédelem alatt álló erdık kezelésére. (Principles for management of natur conservated forestrys). KTM Természetvédelmi Hivatal, Budapest.

LEHMANN A., 1975. A Nagyharsányi Szársomlyó-hegy és növényzete. (The Szársomlyó-hegy of Nagyharsány and its vegetation). MTA Dunántúli Tudományos Intézete, Pécs. 185. 